\title{
Antimicrobial treatment reduces intestinal microflora and improves protein digestive capacity without changes in villous structure in weanling pigs
}

\author{
Thomas Thymann $^{1 *}$, Kristina U. Sørensen ${ }^{1}$, Mette S. Hedemann ${ }^{2}$, Jan Elnif ${ }^{1}$, Bent B. Jensen ${ }^{2}$, \\ Henri Banga-Mboko ${ }^{3}$, Thomas D. Leser ${ }^{4}$ and Per T. Sangild ${ }^{1}$ \\ ${ }^{1}$ University of Copenhagen, Faculty of Life Sciences, Dept. of Human Nutrition, DK-1958 Frederiksberg C, Denmark \\ ${ }^{2}$ University of Aarhus, Faculty of Agricultural Sciences, Dept. of Animal Nutrition and Physiology, DK-8830 Tjele, Denmark \\ ${ }^{3}$ University of Liege, Section of Animal Physiology and Reproduction, 4000 Liege, Belgium \\ ${ }^{4}$ Technical University of Denmark, National Veterinary Institute, Section of Bacteriology, DK-1790 Copenhagen V, Denmark
}

(Received 4 September 2006 - Revised 22 November 2006 - Accepted 5 December 2006)

\begin{abstract}
The immediate post-weaning period is often associated with gut malfunction and diarrhoea for young pigs. Administration of antimicrobials remains an effective way to control weaning diarrhoea but it remains unclear how they affect gut physiology and microbiology although this is a prerequisite for being able to devise better alternatives. Hence, for $7 \mathrm{~d}$ we treated pigs, weaned at $24 \mathrm{~d}$ of age, with a combination of amoxicillin $(25 \mathrm{mg} / \mathrm{kg}$ feed and injection of $8.75 \mathrm{mg} / \mathrm{kg}$ body weight per $12 \mathrm{~h})$ and $\mathrm{ZnO}(2.5 \mathrm{~g} / \mathrm{kg}$ feed). The pigs treated with antimicrobials $(n 11)$ showed no signs of gut malfunction at any time, whereas untreated weaned controls $(n 11)$ developed clinical diarrhoea. The antimicrobial treatment resulted in a higher daily weight gain compared with weaned controls $(101 v .-44 \mathrm{~g} / \mathrm{d}, P<0.0001)$, whereas both groups had a similar degree of villous atrophy compared with unweaned 24-d-old controls $(n 8 ; P<0.05)$. The antimicrobial treatment gave a dramatic reduction in small intestinal microbial diversity, and specifically prevented tissue colonization with Escherichia coli compared with weaned controls. Further, the antimicrobial treatment improved amylase, trypsin and small intestinal aminopeptidase A and N activities (all $P<0 \cdot 05$ ). Specifically for the colon, the antimicrobial treatment was associated with reduced tissue weight $(-23 \%, P<0.05)$, reduced concentration of SCFA $(P<0 \cdot 05)$, and increased mucosal goblet cell area $(P<0 \cdot 0001)$ compared with weaned controls. We conclude that the beneficial effects of antimicrobials are mediated not only through reduction in intestinal bacterial load, but also through a stimulation of protein digestive function and goblet cell density.
\end{abstract}

Microflora: Enzymes: Zinc oxide: Antibiotics: Antimicrobials

Weaning piglets at a relatively early stage in life is often associated with development of intestinal malfunction and symptoms of diarrhoea (Nabuurs et al. 1993). The transition from a milkbased diet to adult-type plant-based diets, combined with the stress of being introduced to new environments, is often followed by a period of low feed intake (Brooks \& Tsourgiannis, 2003). Absence of gut luminal content has detrimental effects on the mucosa (Bertolo et al. 1999; Ganessunker et al. 1999; Burrin et al. 2000) and alters the intestinal microbiota (Gyles, 1993; Jensen, 1998). Drugs like antibiotics and $\mathrm{ZnO}$ have effectively been used as both therapeutics and in-feed growth promoters to block the detrimental effects of weaning. However, the European Union has recently banned the use of antibiotics as in-feed growth promoters, as this may have consequences in terms of increased microbial resistance. The properties of antimicrobials have been researched extensively (Sawai, 2003; Torrallardona et al. 2003; Hojbjerg et al. 2005) but little is known of how the manipulated microflora interacts with gut digestive function and integrity (Commission on Antimicrobial Feed Additives, 1997; Cromwell, 2002; Gaskins et al. 2002). We hypothesized that treatment of weanling pigs with antibiotics, combined with $\mathrm{ZnO}$, is associated with not only marked changes in intestinal microbial community and inflammation, but also in the mucosal digestive and absorptive capacity. Thus, we asked two questions: (1) How does the antimicrobial treatment affect the intestinal microbial community in newly weaned pigs relative to both unweaned and weaned controls? (2) Does antimicrobial treatment improve physiological indices of gut function, like brush border enzyme activity, morphology, integrity and nutrient absorptive capacity relative to both unweaned and weaned controls? Basic understanding of the effects of antimicrobial treatment will help to establish alternative weaning strategies that do not include the use of antimicrobial drugs.

\begin{abstract}
Materials and methods
Experimental design

To test the effects of antimicrobial treatment we chose a spontaneous model of weaning diarrhoea. We selected a commercial weaning facility with a long record of weanling diarrhoea mainly associated with various serotypes of
\end{abstract}


haemolytic $E$. coli. On day 24 postpartum thirty suckling pigs (Landrace $\times$ Yorkshire $\times$ Duroc) from four different sows (Landrace $\times$ Yorkshire) were separated from their dam and allocated into three groups: (1) unweaned control pigs killed for tissue collection immediately after separation from the sow (unweaned control, $n$ 8); (2) treated with antibiotics and $\mathrm{ZnO}$ for $7 \mathrm{~d}$ post-weaning (ANTI group, $n 11$ ); or (3) no treatment for $7 \mathrm{~d}$ post-weaning (weaned control, $n$ 11). All litters were represented with two or three pigs in each treatment group. The pigs from the ANTI and weaned control groups were kept next to each other in two separate pens, and were given ad libitum access to water and dry feed. The composition of the feed is given in Table 1 .

\section{Treatments}

Prior to the study ten faecal samples from pigs in the same weaning facility were collected and tested for sensitivity towards thirty-four different antibiotics belonging to fifteen different groups (sulphonamids, trimethoprims, penicillins, cephalosporins, tetracyclins, aminoglycosides, spectinomycins, macrolides, lincosamides, polymyxins, chloramphinicol, bacitracin, quinolones, tiamulins or fusidin). The sensitivity measured as size of inhibitory zone around an antibiotic tablet on a blood agar, was highest towards the semisynthetic penicillin Synulox (Amoxicillinum trihydricum, potassium clavulanate; Orion Pharma, Nivå, Denmark) which was then mixed into the diet at $25 \mathrm{mg} / \mathrm{kg}$ (of which $20 \mathrm{mg} / \mathrm{kg}$ is amoxicillin and $5 \mathrm{mg} / \mathrm{kg}$ is potassium clavulanate) together with

Table 1. Composition of diet for pigs following weaning

\begin{tabular}{lc}
\hline Diet composition* & \\
\hline Wheat $(\mathrm{g} / \mathrm{kg})$ & 600 \\
Feed supplement mix $(\mathrm{g} / \mathrm{kg}) \dagger$ & 250 \\
Fish meal $(\mathrm{g} / \mathrm{kg})$ & 100 \\
Fat $(\mathrm{g} / \mathrm{kg})$ & 50 \\
Nutrient composition & \\
Net energy $(\mathrm{kJ} / \mathrm{kg})$ & 9727 \\
Crude protein $(\mathrm{g} / \mathrm{kg})$ & 219 \\
Fibre $(\mathrm{g} / \mathrm{kg})$ & 20 \\
Starch $(\mathrm{g} / \mathrm{kg})$ & 355 \\
Fat $(\mathrm{g} / \mathrm{kg})$ & 82 \\
Digestible crude protein $(\mathrm{g} / \mathrm{kg})$ & 195 \\
Digestible lysine $(\mathrm{g} / \mathrm{kg})$ & $14 \cdot 2$ \\
Digestible methionine $(\mathrm{g} / \mathrm{kg})$ & $4 \cdot 8$ \\
Digestible methionine $+\mathrm{cysteine}(\mathrm{g} / \mathrm{kg})$ & $7 \cdot 7$ \\
Digestible threonine $(\mathrm{g} / \mathrm{kg})$ & $8 \cdot 6$ \\
Digestible tryptophan $(\mathrm{g} / \mathrm{kg})$ & $2 \cdot 8$ \\
Calcium $(\mathrm{g} / \mathrm{kg})$ & $8 \cdot 2$ \\
Phosphorus $(\mathrm{g} / \mathrm{kg})$ & $6 \cdot 6$ \\
Digestible $\mathrm{phosphorus}(\mathrm{g} / \mathrm{kg})$ & $4 \cdot 0$ \\
Sodium $(\mathrm{g} / \mathrm{kg})$ & $2 \cdot 5$ \\
Magnesium $(\mathrm{g} / \mathrm{kg})$ & $1 \cdot 3$ \\
Vitamin A $(\mathrm{IU} / \mathrm{kg})$ & 11547 \\
Vitamin $\mathrm{D}_{3}(\mathrm{IU} / \mathrm{kg})$ & 1285 \\
Vitamin E $(\mathrm{IU} / \mathrm{kg})$ & 165 \\
Copper $(\mathrm{mg} / \mathrm{kg})$ & 160 \\
Selenium $(\mathrm{mg} / \mathrm{kg})$ & $0 \cdot 2$ \\
&
\end{tabular}

* Data are expressed per kg feed as fed.

† Based on vitamins, minerals and products and by-products of milk, seed, potatoes and grain (Landmix 2730; Vitfoss, Graasten, Denmark).
$\mathrm{ZnO}$ at $2.5 \mathrm{~g} / \mathrm{kg}$. To ensure sufficient antimicrobial exposure regardless of pig voluntary feed intake Synulox $(17.5 \%)$ was given by intramuscular injection at $0.05 \mathrm{ml} / \mathrm{kg}$ body weight per $12 \mathrm{~h}$. Likewise, weaned control pigs were given an intramuscular injection of saline at $0.05 \mathrm{ml} / \mathrm{kg}$ body weight per $12 \mathrm{~h}$.

\section{Tissue collection}

Seven days post-weaning, all pigs were anaesthetized with Zoletil 50 (zolazepam/tiletamin; Boehringer Ingelheim, Copenhagen, Denmark) and subsequently killed with an intra-cardiac injection of sodium pentobarbitone. Immediately after death, the intestine was excised and sections at $80 \mathrm{~cm}$ caudal to the pyloric sphinter (proximal), $80 \mathrm{~cm}$ cranial to the ileo-caecal valve (distal), and the middle colon, respectively, were excised and transferred to an oxygenated Ringers buffer for in vitro nutrient absorption studies as outlined in previous protocols (Karasov \& Diamond, 1983; Buddington $\&$ Diamond, 1990). Tissue samples from the pancreas and the intestine (proximal, distal and colon) and samples of luminal contents from the distal small intestine and the colon were collected and snap frozen in liquid nitrogen and stored at $-80^{\circ} \mathrm{C}$ for later analysis of digestive enzyme activity, concentration of SCFA and for DNA-based characterization of the microbial community. Weights of the heart, lungs, liver, kidneys, adrenals, spleen, pancreas, stomach and the empty small intestine and colon were recorded, and a score (1, firm well-formed; 2 , soft; 3 , loose; 4 , watery) for the luminal contents of the caecum, colon and rectum was given.

\section{In vitro nutrient absorption}

Measurement of nutrient absorptive function was done according to pre-established protocols (Karasov \& Diamond, 1983; Buddington \& Diamond, 1990). Tissue samples from the proximal and distal small intestine and middle colon were everted, mounted on steel rods and kept 2 min in oxygenated Ringers buffer containing $50 \mathrm{~mm}$ of either glucose, fructose, butyrate (containing $0.01 \mathrm{~mm}-{ }^{14} \mathrm{C}$-labelled tracer), leucine or proline (containing $0.01 \mathrm{mM}$ of ${ }^{3} \mathrm{H}$-labelled tracer), or tracer alone. The samples were weighed and radioactivity levels were subsequently measured on a scintillation counter (Wallac, PerkinElmer, Boston, MA, USA). Calculations of nutrient absorption rates of each individual nutrient were done as outlined by Karasov \& Diamond (1983). Furthermore, as an indication of carrier-dependency, ratios of nutrient accumulation in the presence of tracer alone to presence of tracer in $50 \mathrm{~mm}$ of non-labelled nutrient, were calculated according to Buddington et al. (2000). An accumulation ratio close to 1.0 indicates little competition for carriers, and that a major part of nutrient uptake may occur via carrier-independent mechanisms, whereas accumulation ratios far beyond 1.0 indicate large carrier-dependency.

\section{Enzyme activity}

Activities of lactase-phloridzin (EC 3.2.1.23-62), sucraseisomaltase (EC 3.2.1.48-10), maltase-glucoamylase (EC 3.2.1.20), dipeptidyl-peptidase IV (EC 3.4.14.5), aminopeptidase N (EC 3.4.11.2) and aminopeptidase A (EC 3.4.11.7) 
in homogenates of proximal and distal small intestinal tissue were determined spectrophotometrically using lactose, sucrose, maltose, glycyl-L-prolin-4-nitroanilide, L-alanine-4nitroanilide and $\alpha$-L-glutamic acid 4-nitroanilide as substrates, respectively, according to a previously established protocol (Sangild et al. 1995). Frozen pancreas was homogenized in Tris- $\mathrm{HCl}$ buffer $\left(100 \mathrm{mmol} / \mathrm{l}\right.$ containing $20 \mathrm{mmol} / \mathrm{l} \mathrm{CaCl}_{2}$, $\left.\mathrm{pH} 7.9,2 \mathrm{~min}, 0^{\circ} \mathrm{C}\right)$, centrifuged $\left(20000 \mathrm{~g}, 45 \mathrm{~min}, 4^{\circ} \mathrm{C}\right)$ and the supernatant was used for analysis of amylase, trypsin and chymotrypsin activity. Ethylidene- $p$-nitrophenyl, D-maltoheptaside was used as a substrate for amylase and the released nitrophenol was determined spectrophotometrically at $405 \mathrm{~nm}$ (577-50P; Sigma Chemical Co., St Louis, MO, USA). Benzoyl-arginine- $p$-nitroanilide was used as the substrate for trypsin after activation of trypsinogen with enterokinase (B 4875 and E 0632; Sigma), and chymotrypsin was measured using Succ-AAPF- $p$-nitroanilide (S 7388; Sigma). For all enzymes, a hydrolytic rate of $1 \mu \mathrm{mol}$ substrate hydrolysed $/ \mathrm{min}$ at $37^{\circ} \mathrm{C}$ was considered to represent $1 \mathrm{U}$ of enzyme activity. Enzyme activities were expressed per $\mathrm{g}$ wet intestine or pancreas.

\section{Plasma pepsinogen}

Blood samples were collected from each pig at the time of killing. Plasma was isolated upon centrifugation and used for determination of pepsinogen concentration according to the RIA developed by Banga-Mboko et al. (2003). The detection limit of the RIA was $0 \cdot 2 \mathrm{ng} / \mathrm{ml}$. The intra- and inter-assay variations were 8 and $12 \%$, respectively.

\section{$S C F A$}

The concentration of SCFA was measured as described by Jensen et al. (1995). Samples of the colon luminal content were diluted in a sodium hydroxide solution containing 2-ethylbutyric acid as internal standard. The diluted samples were extracted with $\mathrm{HCl}$ and diethyl ether. Following centrifugation $(3000 \mathrm{~g}, 10 \mathrm{~min})$, the ether layer was isolated and added to the reagent $N$-methyl- $N$-t-butyldimethylsilyltrifluoroacetamide. The reaction mixture was incubated at $80^{\circ} \mathrm{C}$ for $20 \mathrm{~min}$ followed by a further incubation at room temperature for $48 \mathrm{~h}$. Finally, the samples were injected into a gas chromatograph and the chromatograms were analysed using HP GC ChemStation software (Technical Lab Services, ON, Canada).

\section{Escherichia coli}

Samples of the luminal content from the distal small intestine were incubated at $37^{\circ} \mathrm{C}$ under aerobic conditions for $18 \mathrm{~h}$ on a blood agar. The presence or absence of haemolytic and non-haemolytic E. coli was subsequently registered and their serotypes identified.

\section{Microbial community}

DNA from samples of distal small intestinal tissue and luminal content were extracted and purified according to Leser et al. (2000) and Ausubel et al. (1988). Briefly, $200 \mathrm{mg}$ sample homogenate were added to $600 \mu \mathrm{l}$ PBS and centrifuged $\left(4^{\circ} \mathrm{C}, 200 \mathrm{~g}, 2 \mathrm{~min}\right)$. The supernatant was isolated and centrifuged $\left(4^{\circ} \mathrm{C}, 12000 \mathrm{~g}, 5 \mathrm{~min}\right)$, upon which the pellet was isolated and resuspended in a Tris- $\mathrm{HCl}-\mathrm{EDTA}$ solution. To lyse the bacterial cells, the suspension was transferred to vials containing zirconia-silica beads and SDS, and subsequently shaken on a high-speed minibead beater (Biospec Products, Bartlesville, OK, USA) for $4 \mathrm{~min}$. The lysed suspensions were centrifuged and proteins and polysaccharides were precipitated using the cetyltrimethylammonium bromide method by Ausubel et al. (1988). The purified DNA was amplified by thirty cycles of PCR using the reaction conditions specified by Leser et al. (2000). Subsequently, the fluorescently labelled PCR product was purified and digested with a restriction enzyme (Cfo I, 20U; Boehringer Mannheim, Mannheim, Germany). Together with standard fragment mixtures (GS-500 ROX and GS-1000 ROX; Applied Biosystems, Foster City, CA, USA), the restriction fragments were loaded on to a denaturing polyacrylamide gel for electrophoresis $(2500 \mathrm{~V}, 40 \mathrm{~mA}, 10 \mathrm{~h})$ and analysed on an automatic sequence analyser (ABI PRISM 373 DNA Sequencer; Applied Biosystems) in Gene-Scan mode. Data on the lengths of restriction fragments were subsequently analysed using the Bionumerics software package (Applied Maths, Austin, TX, USA) with special emphasis on identification of operational taxonomic units (OTU) differentially expressed among treatment groups. The similarity of each OTU to the nearest phylotype was based on the clone library by Leser et al. (2002). Additionally, as an indication of similarities between samples, we calculated the Dice coefficient using the Bionumerics software package. The Dice coefficient reflects the similarity between two individual samples by calculating the ratio of two times the number of terminal restriction fragments (T-RF) in common between two samples, divided by the total number of T-RF in the two samples. The ratio is calculated for all pairwise sample-to-sample combinations, and from this means and their standard errors are calculated within treatment groups, between treatment groups, within sample site (tissue or content) and between sample sites. Finally, we used Bionumerics to search for T-RF that were present in the ANTI group but absent in weaned controls, as this is an indication of the most important microbial differences between the two groups.

\section{Microscopy}

After $24 \mathrm{~h}$ in $10 \%$ neutral buffered formaldehyde, the tissue samples from the proximal and distal small intestine and the colon were carefully cleaned of remaining digesta using deionized water and then transferred to a fresh solution of $10 \%$ neutral buffered formaldehyde. Subsequently, the samples were dehydrated and infiltrated with paraffin wax. Three slides were prepared from each sample, and each slide contained a minimum of four sections cut at $4 \mu \mathrm{m}$, at least $50 \mu \mathrm{m}$ apart. The slides were processed for carbohydrate histochemistry using either the periodic acid-Schiff reaction or Alcian Blue reaction at either $\mathrm{pH} 2.5$ (Alcian Blue 2.5) or pH 1.0 (Alcian Blue 1.0). The periodic acid-Schiff reaction stains neutral mucins, Alcian Blue 2.5 stains carboxylated or sulphated types of acidic mucins, and Alcian Blue 1.0 stains sulphomucins (Kiernan, 1990). Carbohydrate histochemistry on the periodic acid-Schiff- and Alcian Blue-stained samples was evaluated as described previously by Brunsgaard 
(1997). Briefly, fifteen well-oriented villi and crypts were selected on each slide and for each villus and crypt the area of mucin granules with a clear positive reaction for either neutral mucins, acidic mucins or sulphomucins were determined using a computer-integrated microscope and an image analysis system (Quantimet $500 \mathrm{MC}$; Leica, Cambridge, UK) with a monitor. This area included the mucus material present in the crypt lumen. As the histochemical procedure employed in our study stains the granules of all mucous cells (goblet cells and crypt secretory cells) as well as the apical secretion of these cells, these are all included in the measures. The slides processed for neutral mucins were further used to determine area, height and density of villi and crypts, using the image analyses system. Villous height and area as well as crypt depth and area were determined on fifteen well-oriented villi and crypts, respectively. The villi and crypt density were determined as the number of villi or crypts appearing over a defined distance. The density counts of villi and crypts were done at fifteen different sites on each sample. All measures were done using a light microscope at $10 \times$ magnification.

\section{Statistics}

All data, except the results from the molecular terminal restriction fragment length polymorphism (T-RFLP) analysis, were analysed using pig and sow as random variables and treatment as fixed variable in the Mixed procedure of the SAS statistical software program version 8 (SAS Institute, Cary, NC, USA). When a significant treatment effect was identified, differences between two individual means were compared using the PDIFF option in SAS. Probability levels below 0.05 were considered significant. Differences in prevalence of haemolytic and non-haemolytic E. coli were compared with a $\chi^{2}$ test in SAS.

\section{Results}

At weaning all pigs appeared clinically healthy. During the $7 \mathrm{~d}$ post-weaning, pigs from the ANTI group showed no clinical symptoms at any time whereas all pigs in the weaned control group developed weaning diarrhoea within 3-4 d and remained clinically sick until they were killed on day 7 . This led to a daily weight loss in the weaned control group, while there was a net daily weight gain in the ANTI group (Table 2).

Relative to unweaned controls, the ANTI group pigs showed an increase in small intestinal percentage dry mucosa and weights (relative to body weight) of the empty stomach and colon (all $P<0 \cdot 05$; Table 2). Compared with weaned controls, these indices were similar, whereas the relative weight of the colon and the liver were significantly lower in the ANTI group $(P<0.05$; Table 2). Mean plasma level of pepsinogen was higher in the ANTI group compared with both control groups (ANTI group 156.1 (SE 12.2) ng/ml $v$. unweaned controls 89.6 (SE 14.3) $\mathrm{ng} / \mathrm{ml}$ and weaned controls 115.0 (SE 14.0) ng/ml; $P<0.05$ ). There were no apparent differences in stomach mucosal integrity among the groups.

Compared with unweaned control pigs, the ANTI group pigs had increased activity of amylase and maltase but a decreased activity of aminopeptidase $\mathrm{N}$, dipeptidylpeptidase IV and lactase (all $P<0.05$; Fig. 1). There were pronounced differences in digestive enzyme activity between weaned control pigs and the ANTI group in that aminopeptidase $\mathrm{N}$, aminopeptidase A, trypsin and amylase activities were markedly higher in the ANTI group than weaned controls (all $P<0.05$; Fig. 1). Across treatments, small intestinal lactase

Table 2. Average daily gain, luminal content score and organ dimensions in weanling pigs (Mean values with their standard errors)

\begin{tabular}{|c|c|c|c|c|c|c|c|}
\hline & \multicolumn{2}{|c|}{ Unweaned control } & \multicolumn{2}{|c|}{ Weaned control } & \multicolumn{2}{|c|}{ ANTI group } & \multirow[b]{2}{*}{$P$ value* } \\
\hline & Mean & SE & Mean & SE & Mean & SE & \\
\hline$n$ & 8 & & 11 & & 11 & & \\
\hline Average body weight at weaning (g) & 5900 & 369 & 6647 & 425 & 7084 & 482 & \\
\hline Average daily feed intake $(\mathrm{g} / \mathrm{d})$ & & & 81 & & 133 & & \\
\hline Average daily weight gain $(\mathrm{g} / \mathrm{d})$ & - & & $-46^{\mathrm{b}}$ & 25 & $101^{a}$ & 22 & $<0.0001$ \\
\hline Caecum content score $\dagger$ & - & & $3 \cdot 2^{\mathrm{b}}$ & 0.2 & $1 \cdot 7^{\mathrm{a}}$ & 0.1 & $<0.0001$ \\
\hline Colon content score $\dagger$ & - & & $2 \cdot 9^{\mathrm{b}}$ & 0.3 & $1.7^{\mathrm{a}}$ & 0.1 & $<0.001$ \\
\hline Rectum content score $\dagger$ & - & & $2 \cdot 3^{\mathrm{b}}$ & 0.6 & $0 \cdot 6^{\mathrm{a}}$ & 0.2 & $<0.05$ \\
\hline Small intestinal length $(\mathrm{cm} / \mathrm{kg})$ & 154 & 10 & 150 & 10 & 131 & $7 \cdot 00$ & \\
\hline Small intestinal serosal surface $\left(\mathrm{cm}^{2} / \mathrm{kg}\right)$ & 309 & 37 & 325 & 35 & 327 & 35 & \\
\hline Small intestinal dry mucosa (\%) & $49 \cdot 1^{a}$ & $1 \cdot 2$ & $59 \cdot 0^{\mathrm{b}}$ & 0.9 & $63.0^{b}$ & 1.9 & $<0.0001$ \\
\hline Small intestine $(\mathrm{g} / \mathrm{kg})$ & 49.8 & $2 \cdot 6$ & 44.9 & $2 \cdot 6$ & $44 \cdot 8$ & 1.7 & \\
\hline Stomach $(\mathrm{g} / \mathrm{kg})$ & $5 \cdot 6^{\mathrm{a}}$ & 0.30 & $7 \cdot 0^{\mathrm{b}}$ & 0.40 & $7 \cdot 1^{\mathrm{b}}$ & 0.40 & $<0.01$ \\
\hline Colon $(\mathrm{g} / \mathrm{kg}$ ) & $9 \cdot 8^{\mathrm{a}}$ & 1.0 & $15 \cdot 7^{b}$ & 1.0 & $12 \cdot 1^{\mathrm{c}}$ & 0.8 & $<0.05$ \\
\hline Pancreas (g/kg) & 1.5 & 0.2 & $1 \cdot 7$ & 0.3 & $1 \cdot 7$ & 0.2 & \\
\hline Heart $(\mathrm{g} / \mathrm{kg})$ & $5 \cdot 7^{\mathrm{a}}$ & 0.2 & $4.7^{b}$ & 0.2 & $4.9^{b}$ & 0.2 & $<0.01$ \\
\hline Lungs $(\mathrm{g} / \mathrm{kg})$ & $13 \cdot 9^{a}$ & 0.5 & $11.0^{\mathrm{b}}$ & 0.2 & $10 \cdot 1^{\mathrm{b}}$ & 0.2 & $<0.0001$ \\
\hline Liver (g/kg) & $32 \cdot 5^{\mathrm{a}}$ & $1 \cdot 1$ & $30.4^{\mathrm{a}}$ & $1 \cdot 3$ & $24 \cdot 8^{\mathrm{b}}$ & 0.8 & $<0.001$ \\
\hline Kidney $(\mathrm{g} / \mathrm{kg})$ & $3 \cdot 6^{\mathrm{a}}$ & 0.3 & $2 \cdot 7^{\mathrm{b}}$ & 0.3 & $2 \cdot 6^{b}$ & 0.1 & $<0.05$ \\
\hline Spleen (g/kg) & $6 \cdot 3^{\mathrm{a}}$ & 0.2 & $6 \cdot 2^{a b}$ & 0.4 & $5 \cdot 4^{b}$ & $0 \cdot 1$ & $<0.05$ \\
\hline Adrenals ( $\mathrm{g} / \mathrm{kg}$ ) & 0.15 & 0.02 & 0.16 & 0.02 & 0.12 & 0.02 & \\
\hline
\end{tabular}

ANTI group, antimicrobial group.

a,b,c Mean values within a row with unlike superscript letters were significantly different $(P<0.05)$.

${ }^{\star} P$ values refer to the overall treatment effect.

$\dagger 1$, firm well-formed; 2 , soft; 3 , loose; 4 , watery. 

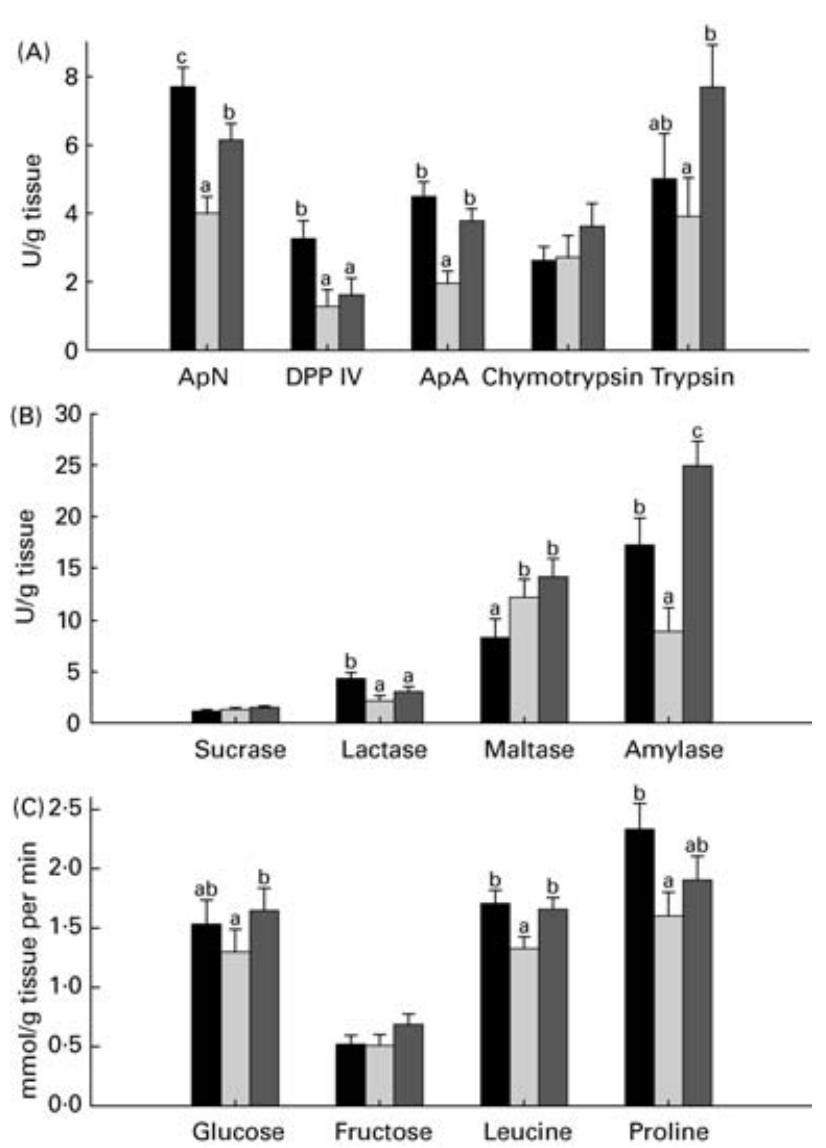

Fig. 1. Enzyme activities (expressed as $U / g$ tissue) of aminopeptidase $N$ $(\mathrm{ApN})$, dipeptidylpeptidase IV (DPP IV), aminopeptidase A (ApA), chymotrypsin and trypsin (A), and sucrase, lactase, maltase and amylase (B). (C), Small intestinal in vitro absorption rate, expressed as $\mathrm{mmol} / \mathrm{g}$ tissue per min of glucose, fructose, leucine and proline. Values are means with their standard errors depicted by vertical bars. ${ }^{a, b}$ Mean values with unlike letters were significantly different $(P<0.05)$. $\square$, Unweaned control; $\square$, weaned control; $\square$, antimicrobial group.

and peptidase activity was higher in the proximal than in the distal intestine, whereas sucrase and maltase activity was similar in both regions (regional results not shown).

In vitro mucosal uptake of the most carrier-dependent nutrients, glucose and leucine (data for carrier-dependency not shown), were significantly higher in the ANTI group compared with weaned controls $(P<0 \cdot 05)$, whereas the less carrier-dependent uptakes of fructose and proline were similar between these groups (Fig. 1). In vitro absorption rate of butyrate showed a clear $\mathrm{pH}$-dependency $(7.6 \mathrm{mmol} / \mathrm{g}$ tissue per $\min$ at $\mathrm{pH} 2.5$ v. $4.2 \mathrm{mmol} / \mathrm{g}$ tissue per min at $\mathrm{pH} 5.5$, $P<0.001$ ), but there was no effect of treatment.

Relative to unweaned controls, morphometric analysis showed a significant decrease in villous height and an increase in crypt depth in the ANTI group $(P<0 \cdot 05)$, whereas the morphometric measures were similar between the ANTI group and weaned controls (Fig. 2). However, goblet cells in the colon stained with either Alcian Blue ( $\mathrm{pH} 1.0$ or 2.5) or periodic acid-Schiff showed marked differences in that weaned control pigs had a reduced area of stained goblet cells compared with the ANTI group (Figs. 3 and 4; $P<0.001$ ). Levels in the small intestine were similar among all three

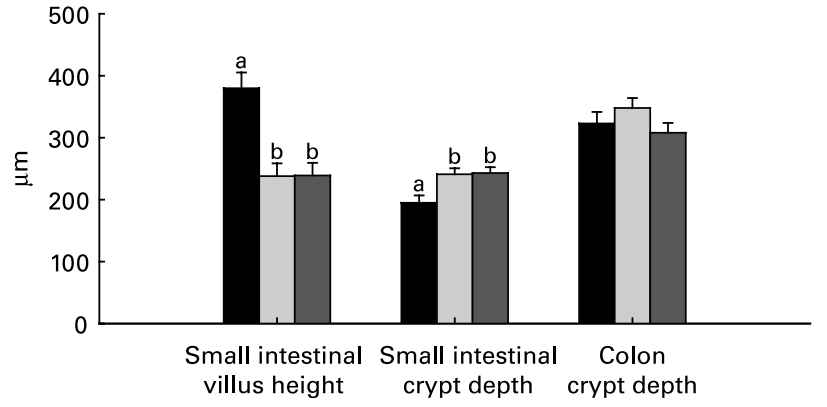

Fig. 2. Morphometric dimensions of the small and large intestine expressed in $\mu \mathrm{m}$. Values are means with their standard errors depicted by vertical bars. a,b Mean values with unlike letters were significantly different $(P<0.05)$. Unweaned control; $\square$, weaned control; $\square$, antimicrobial group.

groups (Fig. 4). Compared with weaned controls, antimicrobial treatment significantly reduced the concentration of acetic acid (34.0 (SE 4.0) v. 57.3 (SE 3.2) $\mathrm{mmol} / \mathrm{kg}$, $P<0.05$ ), propionic acid (18.1 (SE 1.7) v. 24.5 (SE 2.2) $\mathrm{mmol} / \mathrm{kg}, P<0.05$ ) and butyric acid (1.6 (SE 0.5) v. 5.5 (SE 1.2) $\mathrm{mmol} / \mathrm{kg}, \quad P<0.01$; Fig. 5). These three acids accounted for over $80 \%$ of the total SCFA found in the colon in all treatment groups.

The effect of antimicrobial treatment was also evaluated by the prevalence of haemolytic and non-haemolytic E. coli in distal small intestinal contents, as well as by T-RFLP using distal small intestinal contents and tissue. The prevalence of haemolytic E. coli was $13 \%$ in the ANTI group v. $56 \%$ in weaned controls. One pig in the weaned control group had both haemolytic and non-haemolytic E. coli, whereas all other pigs had either only haemolytic or non-haemolytic E. coli. Based on a $\chi^{2}$ test, the prevalence of haemolytic $E$. coli between the ANTI group and weaned controls was significantly different

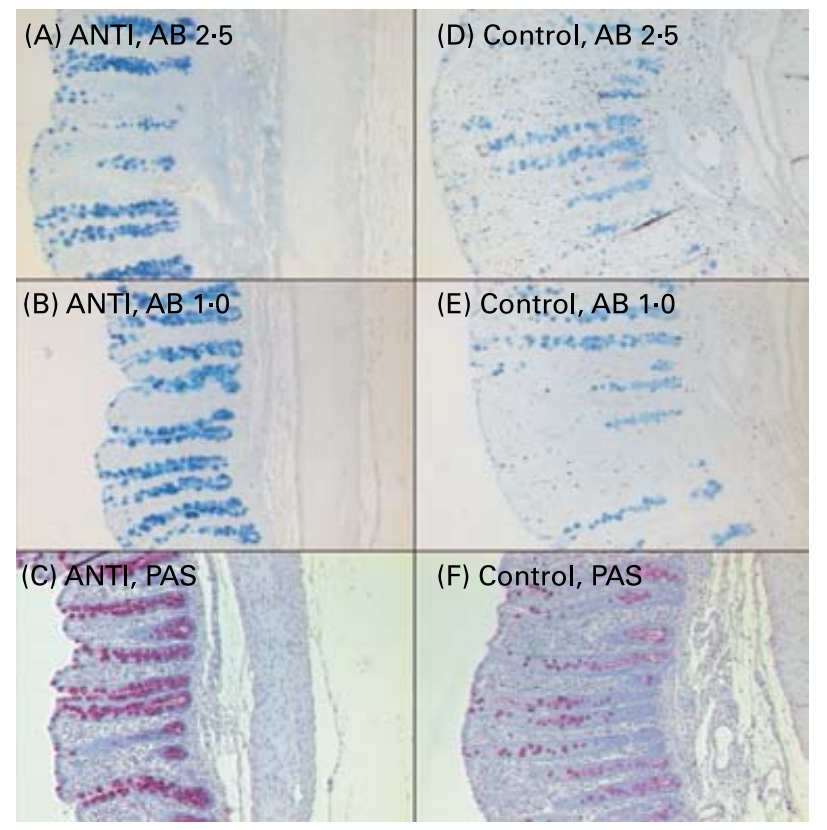

Fig. 3. Mucus-containing goblet cells in the colon of pigs treated with antimicrobials (ANTI; $A-C$ ) and weaned control pigs (D-F) using three different stainings: Alcian Blue (AB) pH $2.5(A, D), A B ~ p H ~ 1.0(B, E)$ or periodic acidSchiffs reagent (PAS; $C, F)$. 


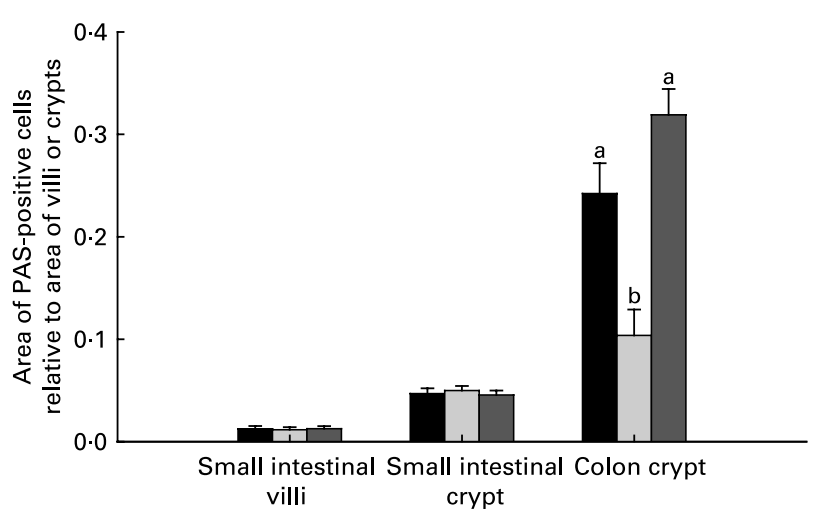

Fig. 4. Area of mucus-containing goblet cells in the small and large intestine. Data are expressed as area of positively stained cells relative to villus or crypt area using periodic acid-Schiffs reagent (PAS). Stainings with Alcian Blue gave similar results as PAS (data not shown). Values are means with their standard errors depicted by vertical bars. ${ }^{a, b}$ Mean values with unlike letters were significantly different $(P<0.05)$. $\square$, Unweaned control; $\square$, weaned control; $\square$, antimicrobial group.

$(P<0.001)$. The non-haemolytic $E$. coli found in the ANTI group seemed to belong to a single subtype, whereas both haemolytic and non-haemolytic E. coli in the weaned control group came from various subtypes, including O149, O157, O8, O138 and O45. Using the T-RFLP technique, the intestinal microbial diversity in the luminal content expressed as total number of identified T-RF within a treatment group was markedly lower for the ANTI group than for unweaned controls and weaned controls (Fig. 6), whereas the diversity at the tissue level was similar between groups. Dice pairwise similarity coefficients were calclulated within and between treatment groups as well as within and between sample sites (tissue or content) (Table 3). Generally the similarity was larger within sample sites than between them. The low similarity between content and tissue was accounted for by the lower number of T-RF in the tissue compared with content, indicating that tissue-associated bacteria represent only a subfraction of those found in the lumen. Further, as a direct consequence of the markedly reduced diversity in the ANTI group, they showed only little similarity

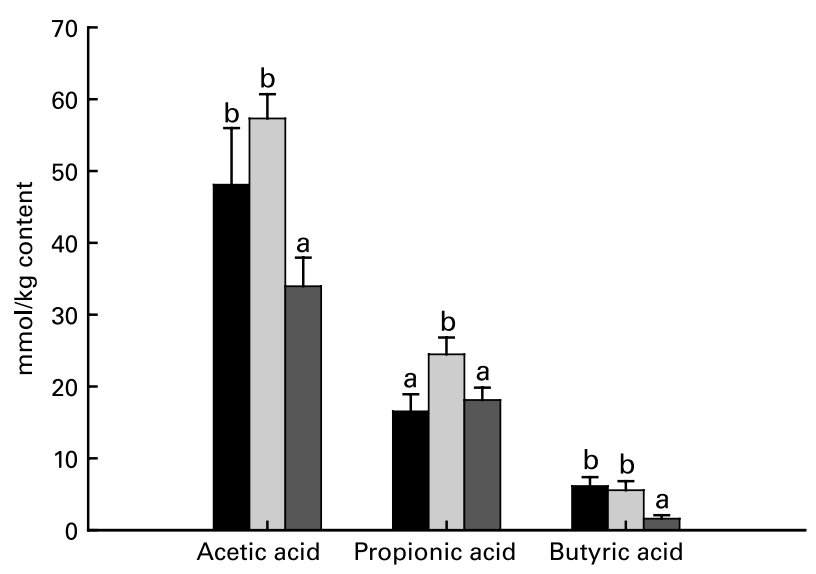

Fig. 5. Concentration of acetic acid, propionic acid and butyric acid in colon luminal content ( $\mathrm{mmol} / \mathrm{kg}$ content). Values are means with their standard errors depicted by vertical bars. ${ }^{a, b}$ Mean values with unlike letters were sig-

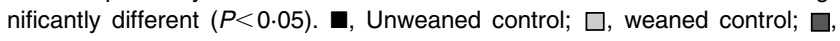
antimicrobial group. with weaned controls. The most dominating T-RF were found at 37, 61 and $407 \mathrm{bp}$, and in the range 594-598 bp (Fig. 6; Table 4). Based on a swine-specific database of OTU using the Cfo I restriction enzyme (Leser et al. 2002), phylogenetic similarities of the most dominating OTU to culturable bacteria are given in Table 4. Lactobacilli appeared to be very dominating in all treatment groups in both tissue and content. Finally, using the Bionumerics software package we did an analysis with the purpose of identifying T-RF that were frequently present in weaned control pigs (with diarrhoea), but absent in the ANTI group (healthy) pigs. Four different OTU were found of which two showed high similarity to strains of lactobacilli, one had high similarity to $E$. coli and one was unknown (Table 5). Since the prevalence of the four identified OTU seemed to be the same in the content but different in tissue in healthy (ANTI group) $v$. sick (weaned control) pigs, the present data suggest that bacteria associated with weanling diarrhoea are mostly found at the tissue level and not in luminal content.

\section{Discussion}

Selecting a commercial production site with a record of weanling diarrhoea resulted in major clinical differences between the ANTI group and weaned control pigs. Within $4-5 \mathrm{~d}$ post-weaning, all pigs in the weaned control group developed diarrhoea whereas there were no signs of intestinal dysfunction in the ANTI group at any time. This could be related to a stimulation of intestinal peptidase and pancreatic amylase activties in the ANTI group, coupled with an improved absorption rate specifically for carrier-dependent nutrients like glucose and leucine. Despite the marked clinical differences there was surprisingly little difference in the weaning-associated villous atrophy (Hampson, 1986; Miller et al. 1986; Pluske et al. $1996 a, b$ ) which was similar in the two weaned groups compared with unweaned control pigs.

We also observed a large treatment effect on the mucuscontaining goblet cells in the colon. The dramatic reduction in the colon of weaned control pigs seems to reflect an accelerated secretion to the lumen due to increased exposure to pathogens like haemolytic E. coli. The epithelial mucosal lining serves a protective function against pathogens. Production and secretion of mucus by goblet cells is partly continuous, providing for the renewal of mucus lost by erosion, but also partly accelerated when challenged by pathogens (Epple et al. 1997). Conventional culturing of faecal samples confirmed that the prevalence of haemolytic E. coli was higher in weaned control pigs than in the ANTI group. The antibiotic we chose was a $\beta$-lactam (amoxicillin) which was combined with a $\beta$-lactamase inhibitor (clavulanate) that restores its potency against $\beta$-lactamase-producing bacteria like E. coli. However, not all strains of $E$. coli display the same sensitivity towards this combination (Bronner et al. 2002). We therefore hypothesize that the present antibiotic has selected strains of $E$. coli that were resistant to $\beta$-lactam, and that these resistant strains were predominantly non-haemolytic as no haemolytic E. coli were found in the ANTI group.

Our DNA-based characterization of the microflora using T-RFLP confirmed that E. coli present in the tissue, but not in luminal content, account for some of the differences observed in the microbiota between the ANTI group and weaned controls. The present finding is consistent with other 


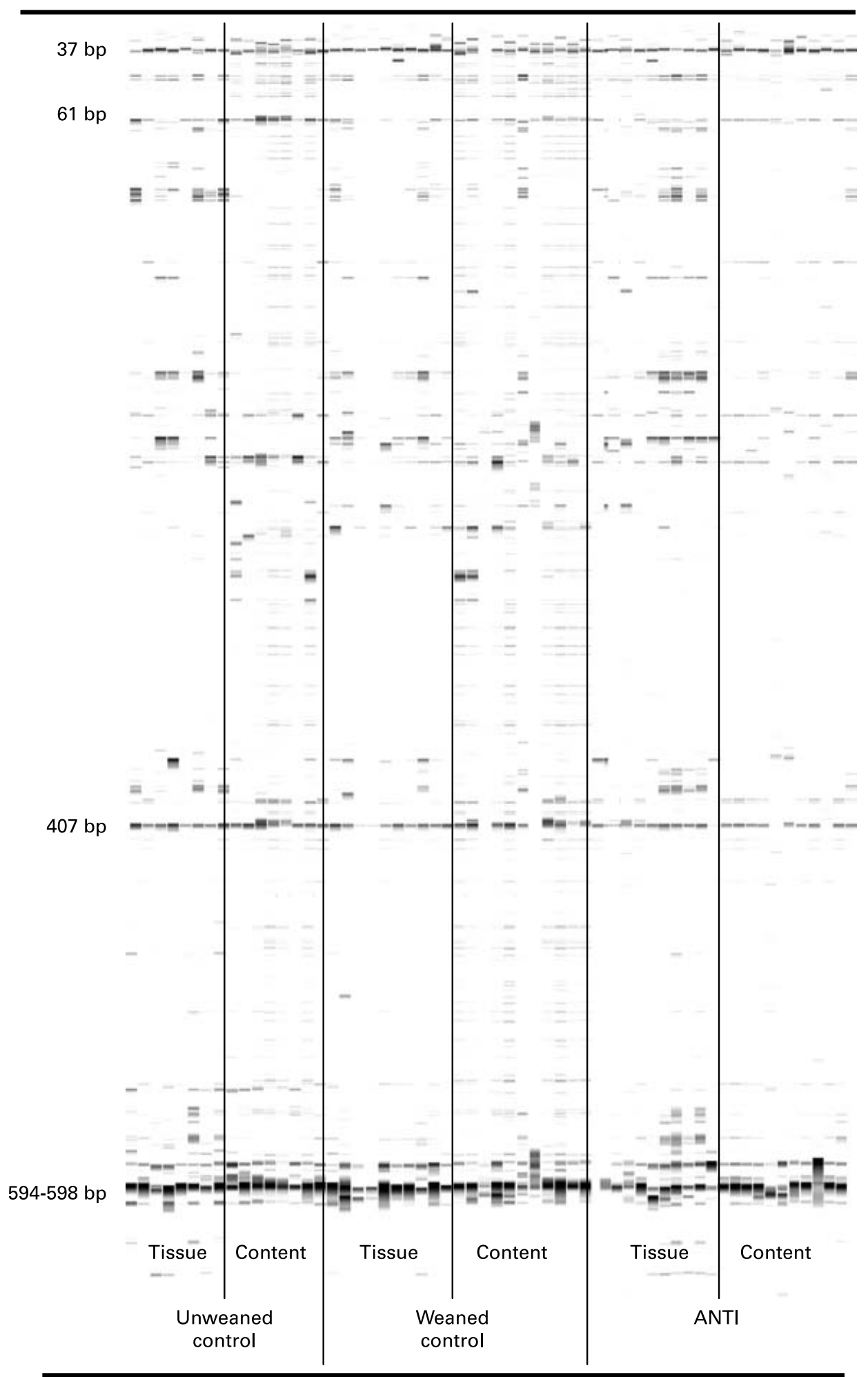

Fig. 6. Gel containing bands of restriction fragments of bacterial 16S DNA from samples of distal small intestinal tissue and luminal content. The restriction fragment lengths of the four most dominating bands are indicated as number of base pairs. ANTI, antimicrobial group.

studies on the mucosal adhesive properties of E. coli and its role in the pathogenesis of weaning diarrhoea (Gyles, 1993; Bronner et al. 2002; Grange et al. 2002). It is interesting that weaned control pigs more often also harboured certain strains of lactobacilli in the tissue, compared with the ANTI group pigs. The present observation does not prove that the particular strains of lactobacilli are part of the pathogenesis, nor does it prove that they are potential beneficial probiotics. However, the massive T-RF observed at $407 \mathrm{bp}$ and 594$596 \mathrm{bp}$ in all treatment groups were identified as different 
Table 3. Dice pairwise similarity coefficients within and between treatments*

(Mean values with their standard errors)

\begin{tabular}{|c|c|c|c|c|c|c|c|c|c|c|c|c|c|}
\hline & & \multicolumn{4}{|c|}{ Unweaned control } & \multicolumn{4}{|c|}{ ANTI group } & \multicolumn{4}{|c|}{ Weaned control } \\
\hline & & \multicolumn{2}{|c|}{ Tissue } & \multicolumn{2}{|c|}{ Content } & \multicolumn{2}{|c|}{ Tissue } & \multicolumn{2}{|c|}{ Content } & \multicolumn{2}{|c|}{ Tissue } & \multicolumn{2}{|c|}{ Content } \\
\hline & & Mean & SE & Mean & $\mathrm{SE}$ & Mean & $\mathrm{SE}$ & Mean & SE & Mean & SE & Mean & SE \\
\hline \multirow[t]{2}{*}{ Unweaned control } & Tissue & $63.4^{c}$ & 2.5 & $51 \cdot 7^{\mathrm{b}}$ & $2 \cdot 1$ & - & & - & & - & & - & \\
\hline & Content & - & & $55 \cdot 2^{b}$ & 3.6 & - & & - & & - & & - & \\
\hline \multirow[t]{2}{*}{ ANTI group } & Tissue & $64 \cdot 5^{\mathrm{c}}$ & 1.8 & - & & $64 \cdot 5^{\mathrm{cd}}$ & $3 \cdot 6$ & $56 \cdot 1^{b}$ & 1.3 & - & & - & \\
\hline & Content & - & & $52 \cdot 7^{\mathrm{b}}$ & 1.9 & - & & $63 \cdot 5^{\mathrm{c}}$ & $2 \cdot 6$ & - & & - & \\
\hline \multirow[t]{2}{*}{ Weaned control } & Tissue & $64 \cdot 8^{\mathrm{c}}$ & $1 \cdot 3$ & - & & $39 \cdot 4^{\mathrm{a}}$ & $1 \cdot 2$ & - & & $68 \cdot 2^{\mathrm{cd}}$ & 1.3 & $42 \cdot 6^{\mathrm{a}}$ & $1 \cdot 3$ \\
\hline & Content & - & & $63 \cdot 6^{c}$ & $2 \cdot 3$ & - & & $39 \cdot 7^{\mathrm{a}}$ & 1.5 & - & & $70 \cdot 5^{\mathrm{d}}$ & $2 \cdot 3$ \\
\hline
\end{tabular}

ANTI group, antimicrobial group.

a,b,c,d Mean values with unlike superscript letters were significantly different $(P<0.05)$.

* Data are expressed as percentages. Within each set of comparisons, results represent means, with their standard errors, of all pairwise sample-to-sample comparisons. Every sample-to-sample comparison was calculated as two times the number of terminal restriction fragments they have in common, divided by the total number of terminal restriction fragments for the two samples.

strains of lactobacilli which suggests that this group of bacteria requires special attention. Jensen (1998) found an inverse relationship between numbers of coliforms and lactobacilli in the intestine, such that coliforms proliferate initially during the first $2-3 \mathrm{~d}$ post-weaning, but are subsequently substituted by lactobacilli on days 3-7. In their study the shift towards more lactobacilli was associated with an increase in fecal DM, indicating recovery from weanling diarrhoea. In the present study, however, pigs in the weaned control group showed no signs of recovery 1 week after weaning but did have high numbers of lactobacilli as indicated by intense T-RF at 407 and 594-596 bp (Fig. 6). Therefore, high levels of lactobacilli in a late post-weaning phase (days 4-7) does not seem to provide sufficient colonization resistance against pathogens under the given circumstances. High levels of lactobacilli in a compromised intestine may even result in growth depression of the host via competition for luminal nutrients and/or altered fat digestion by deconjugating bile salts (Engberg et al. 2000).

Intestinal colonization resistance against pathogens is an important function of the large intestine in addition to its role in the absorption of water, electrolytes and SCFA. In non-pathological conditions, large intestinal fermentation

Table 4. Dominating terminal restriction fragments (T-RF) in tissue and content and list of potential operational taxonomic units (OTU) and tentative bacterial identification (for details see Fig. 6)

\begin{tabular}{lrrl}
\hline & & $\begin{array}{r}\text { Phylogenetic similarity of OTU to the } \\
\text { nearest culturable bacteria* }\end{array}$ \\
\cline { 3 - 4 } T-RF (bp) & OTU & $\%$ & \multicolumn{1}{c}{ Bacteria } \\
\hline 37 & 107 & $96 \cdot 6$ & Faecalibacterium prausnitzii \\
61 & 47 & $98 \cdot 4$ & Lactobacillus vaginalis \\
61 & 301 & $99 \cdot 3$ & Lactobacillus pontis \\
61 & 341 & $99 \cdot 2$ & Lactobacillus panis \\
407 & 173 & $99 \cdot 5$ & Lactobacillus reuteri \\
595 & 50 & $96 \cdot 3$ & Lactobacillus delbrueckii \\
596 & 171 & $97 \cdot 3$ & Lactobacillus amylovorus \\
598 & 271 & $96 \cdot 2$ & Lactobacillus plantarum \\
598 & 289 & $97 \cdot 6$ & Lactobacillus brevis \\
598 & 302 & $97 \cdot 0$ & Lactobacillus collinoides
\end{tabular}

* Only bacterial strains displaying more than $96 \%$ phylogenetic similarity to specific OTU are included. is considered beneficial because SCFA provide energy to the epithelium and serve as co-factors in the absorption of electrolytes (Ruppin et al. 1980; van Beers-Schreurs et al. 1998). In contrast to this, the present study shows that controlling weanling diarrhoea with antimicrobials reduces the concentration of SCFA in the colon luminal content. We suggest that antimicrobial treatment prevents large intestinal fermentation of readily fermentable substrates, like starch and protein, via its stimulating effects on digestive enzymes and nutrient absorption in the small intestine, coupled with its general inhibition of bacterial load and specific inhibition of certain tissue-associated pathogens. In weaned control pigs rapid fermentation in the colon may result in tissue damage and body dehydration due to accumulation of osmotic active components like SCFA and electrolytes in the lumen. It is likely that the increased size of the colon in the weaned control group reflects accelerated, yet insufficient, adaptation toward absorbing SCFA from excess fermentation. We have shown that in vitro absorption of SCFA in the colon, exemplified by butyrate, is stimulated by low $\mathrm{pH}(\mathrm{pH} 2.5$ v. 5.5). However, as in vivo luminal $\mathrm{pH}$ drops only from approximately $7 \cdot 2$ to 6.2 within $7 \mathrm{~d}$ post-weaning (Jensen, 1998), there may not be any $\mathrm{pH}$-dependency at all in this range (Rechklemmer \& von Engelhardt, 1988). Thus, colon luminal $\mathrm{pH}$ may be suboptimal for absorption in situations of bacterial overgrowth and supply of readily fermentable substrates not digested in the small intestine. Readily fermentable substrates include simple carbohydrates and protein, whereas fibrous components in the diet are known to provide a slower fermentation that are less likely to exceed the SCFA absorptive capacity.

Deficiency of dietary fibrous components has been shown to make the colonic mucosa more fragile and prone to spontaneous bleeding in rats (Strugala et al. 2003). Relative to oat- or barleycontaining diets, the level of NSP in the present experiment was relatively low due to the high content of wheat. We speculate that the interactive effect of the markedly lower feed intake observed for weaned control pigs, and the low dietary level of NSP, resulted in prolonged retention of digesta in the colon leading to increased erosion of the colonic mucus. Erosion of the protective mucus layer exposes the epithelial cells and makes them vulnerable to pathogens that induce inflammation, leading to further malfunction of the colon (Liu et al. 2005). Treating weanling 
Table 5. Prevalence of discriminative terminal restriction fragments (T-RF) that are differentially expressed between treatment groups (size of T-RF and suggestions for operational taxonomic unit (OTU) and tentative bacterial identifications are given)*

\begin{tabular}{|c|c|c|c|c|c|c|c|}
\hline \multirow[b]{2}{*}{ T-RF (bp) } & \multirow[b]{2}{*}{ OTU } & \multicolumn{2}{|c|}{$\begin{array}{l}\text { Phylogenetic similarity of OTU to the } \\
\text { nearest culturable bacteria }\end{array}$} & \multicolumn{2}{|c|}{ ANTI group } & \multicolumn{2}{|c|}{ Weaned control } \\
\hline & & $\%$ & Bacteria & Tissue & Content & Tissue & Content \\
\hline 223 & 353 & $95 \cdot 7$ & Lactobacillus delbruecki & $0 / 11$ & $9 / 11$ & $8 / 11$ & $9 / 11$ \\
\hline 250 & & Unknown & & $1 / 11$ & $9 / 11$ & $7 / 11$ & $8 / 11$ \\
\hline 262 & 208 & 93.9 & Lactobacillus sharpeae & $4 / 11$ & $9 / 11$ & $7 / 11$ & $10 / 11$ \\
\hline 373 & 1 & $97 \cdot 0$ & Escherichia coli & $3 / 11$ & $5 / 11$ & $7 / 11$ & $6 / 11$ \\
\hline
\end{tabular}

ANTI group, antimicrobial group.

${ }^{*}$ Results represent number of samples containing a specific T-RF/total number of samples within treatment group.

pigs with antimicrobials effectively blocks the pathogenic pathway, probably by reducing the number of entero-toxigenic bacteria in the small intestine and the colon, and thereby stabilizing the mucosal integrity. Further, it is likely that reducing the luminal load of both pathogenic and non-pathogenic bacteria in the colon provides fermentation that does not exceed the absorptive capacity and therefore leads to retention of water and electrolytes, rather than dehydration.

Intestinal digestive enzymes and absorptive functions, especially those related to protein digestion, were significantly improved by antimicrobial treatment. Likewise, the increase in plasma pepsinogen levels may reflect enhanced protease synthetic capacity in the stomach in healthy pigs. In a recent study, small intestinal peptidase activity declined during the first $3 \mathrm{~d}$ post-weaning, but then increased as a sign of recovery (Hedemann et al. 2003). In the present study, however, pigs in the weaned control group never recovered from weaningassociated digestive malfunction and this was reflected as reduced protein digestive capacity compared with the ANTI group. Together, these effects could contribute to the hypothesis that reducing protein contents in weaning diets without antimicrobials is beneficial to avoid maldigestion. Considering the reduced feed intake for weaned control pigs, which in itself is a risk factor (Madec et al. 1998), it appears, however, that lowered digestive and absorptive capacity is not the only factor leading to weanling diarrhoea. Stasis of luminal content in the small intestine due to low feed intake immediately after weaning, allowing adhesion of entero-toxigenic bacteria like E. coli, could be a key factor leading to maldigestion and diarrhoea in the present experiment.

The present study showed that treating weanling pigs with antimicrobials alters the microflora and improves digestive enzyme activity and goblet cell density. Based on the present study, alternatives to antimicrobials are most likely to be found in interventions that specifically prevent or limit tissue colonization of haemolytic $E$. coli, or generally reduce the intestinal bacterial load. In addition, interventions that improve protein digestive function in the small intestine and/or controls fermentation in the large intestine could possibly simulate the beneficial effects of antimicrobials.

\section{Acknowledgements}

This work was presented as an abstract at the 9th International Symposium on Digestive Physiology in Pigs (Banff, Canada, 2003): 'Effects of GLP-2 treatment and antibiotics on gut structure and function during pig weanling diarrhoea', pp. 161-163, Department of Agricultural and Nutritional Science, University of Alberta. Anna Siekierska, Katja Kristensen, Thomas Rebsdorf, Mie Lilleris Nielsen and Kathrine Hansen Høirup are greatly thanked for their skilful handling of laboratory procedures. This work was funded by a grant from the Directorate for Food, Fisheries and Agri Business.

\section{References}

Ausubel FM, Brent R, Kingston RE, Moore DD, Smith JA, Seidman JG \& Stuhl K (1988) Preparation and analysis of DNA. In Current Protocols in Molecular Biology, pp. 2.4.1-2.4.5 [FM Ausubel, editor]. New York: Wiley.

Banga-Mboko H, Sulon J, Closset J, Remy B, Youssao I, De Sousa NM, El Amiri B, Sangild PT, Maes D \& Beckers JF (2003) An improved radioimmunoassay for measurement of pepsinogen in porcine blood samples. Vet $J \mathbf{1 6 5}, 288-295$.

Bertolo RFP, Chen CZL, Pencharz PB \& Ball RO (1999) Intestinal atrophy has a greater impact on nitrogen metabolism than liver by-pass in piglets fed identical diets via gastric, central venous or portal venous routes. J Nutr 129, 1045-1052.

Bronner S, Murbach V, Peter JD, Levêque D, Elkhaïli H, Salmon Y, Dhoyen N, Monteil H, Woodnutt G \& Jehl F (2002) Ex vivo pharmacodynamics of amoxicillin-clavulanate against $\beta$-lactamase-producing Escherichia coli in Yucatan miniature pig model that mimics human pharmacokinetics. Antimicrob Agents Chemother 46, 3782-3789.

Brooks PH \& Tsourgiannis CA (2003) Factors affecting the voluntary feed intake of the weaned pig. In Weaning the Pig, pp. 81-116 [JR Pluske, J Le Dividich and MWA Verstegen, editors]. Wageningen: Academic Publishers.

Brunsgaard G (1997) Morphological characteristics, epithelial cell proliferation, and crypt fission in cecum and colon of growing pigs. Dig Dis Sci 42, 2384-2393.

Buddington RK \& Diamond JM (1990) Ontogenetic development of nutrient transporters in rabbit intestine. Am J Physiol Gastrointest Liver Physiol 259, 544-555.

Buddington RK, Malo C, Sangild PT \& Elnif J (2000) Intestinal transport of monosaccharides and amino acids during postnatal development of mink. Am J Physiol Regul Integr Comp Physiol 279, 2287-2296.

Burrin DG, Stoll B, Jiang R, Hartmann B, Holst JJ, Greely GH \& Reeds PJ (2000) Minimal enteral nutrient requirements for intestinal growth in neonatal piglets: how much is enough? Am J Clin Nutr 71, 1603-1610.

Commission on Antimicrobial Feed Additives (1997) Antimicrobial feed additives. In Government Official Reports, SOU, pp. 49-83. Stockholm: Swedish Ministry of Agriculture. 
Cromwell GL (2002) Why and how antibiotics are used in swine production (review). Anim Biotechnol 13, 7-27.

Engberg RM, Hedemann MS, Leser TD \& Jensen BB (2000) Effect of zinc bacitracin and salinomycin on intestinal microflora and performance of broilers. Poult Sci 79, 1311-1319.

Epple HJ, Kreusel KM, Hanski C, Schulzke JD, Reicken EO \& Fromm M (1997) Differential stimulation of intestinal mucin secretion by cholera toxin and carbachol. Pflugers Arch 433, $638-647$.

Ganessunker D, Gaskins HR, Zuckermann FA \& Donovan SM (1999) Total parenteral nutrition alters molecular and cellular indices of intestinal inflammation in neonatal piglets. $J$ Parenter Enteral Nutr 23, 337-644.

Gaskins RH, Collier CT \& Anderson DB (2002) Antibiotics as growth promotants: mode of action. Anim Biotechnol 13, 29-42.

Grange PA, Mouricout MA, Levery SB, Francis DH \& Erickson AK (2002) Evaluation of receptor binding specificity of Escherichia coli K88 (F4) fimbrial adhesin variants using porcine serum transferrin and glycosphingolipids as model receptors. Infect Immun 70, $2336-2343$.

Gyles CL (1993) Escherichia coli. In Pathogenisis of Bacterial Infections in Animals, pp. 164-187 [CL Gyles and CO Thoen, editors]. Ames: Iowa State University Press.

Hampson DJ (1986) Atempts to modify changes in the piglet small intestine after weaning. Res Vet Sci 40, 313-317.

Hedemann MS, Hojsgaard S \& Jensen BB (2003) Small intestinal morphology and activity of intestinal peptidases in piglets around weaning. J Anim Physiol Anim Nutr 87, 32-41.

Hojbjerg O, Canibe N, Poulsen HD, Hedemann MS \& Jensen BB (2005) Influence of dietary zinc oxide ( $\mathrm{ZnO})$ and copper sulphate $\left(\mathrm{CuSO}_{4}\right)$ on the gastrointestinal ecosystem in newly weaned piglets. Appl Environ Microbiol 71, 2267-2277.

Jensen BB (1998) The impact of feed additives on the microbial ecology of the gut in young pigs. J Anim Feed Sci 7, 45-64.

Jensen MT, Cox RP \& Jensen BB (1995) Microbial production of skatole in the hind gut of pigs given different diets and its relation to skatole deposition in backfat. Anim Sci 61, 293-304.

Karasov WH \& Diamond JM (1983) A simple method for measuring solute uptake by intestine in vitro. J Comp Physiol 152, 105-116.

Kiernan JA (1990) Histological and Histochemical Methods: Theory and Practice, 2nd ed. Oxford: Pergamon Press.

Leser TD, Amenuvor JZ, Jensen TK, Lindecrona RH, Boye M \& Møller K (2002) Culture-independent analysis of gut bacteria: the pig gastrointestinal tract microbiota revisited. Appl Environ Microbiol 68, 673-690.

Leser TD, Lindecrona RH, Jensen TK, Jensen BB \& Møller K (2000) Changes in bacterial community structure in the colon of pigs fed different experimental diets and after infection with Brachyspira hyodysenteriae. Appl Environ Microbiol 66, 3290-3296.

Liu L, Fishman ML, Hicks KB \& Kende M (2005) Interaction of various pectin formulations with porcine colonic tissues. Biomaterials 26, 5907-5916.

Madec F, Bridoux N, Bounaix S \& Jestin A (1998) Measurement of digestive disorders in the piglet at weaning and related risk factors. Prev Vet Med 35, 53-72.

Miller BG, James PS, Smith MW \& Bourne FJ (1986) Effect of weaning on the capacity of pig intestinal villi to digest and absorb nutrients. J Agri Sci 107, 579-589.

Nabuurs MJA, Hoogendoorn A, van der Molen EJ \& van Osta ALM (1993) Villous height and crypt depth in weaned and unweaned pigs, reared under various circumstances in the Netherlands. Res Vet Sci 55, 78-84.

Pluske JR, Williams IH \& Aherne FX (1996a) Maintenance of villous height and crypt depth in piglets by providing continuoues nutrition after weaning. Anim Sci 62, 131-144.

Pluske JR, Williams IH \& Aherne FX (1996b) Villous height and crypt depth in piglets in response to increases in the intake of cows' milk after weaning. Anim Sci 62, 145-158.

Rechklemmer G \& von Engelhardt W (1988) Concentration- and pHdependence of short-chain fatty acid absorption in the proximal and distal colon of guinea pig. Comp Biochem Physiol 91, 659-663.

Ruppin H, Bar-Meir S, Soergel KH, Wood CM \& Schmitt MG Jr (1980) Absorption of short-chain fatty acids by the colon. Gastroenterology 78, 1500-1507.

Sangild PT, Sjostrom H, Noren O, Fowden AL \& Silver M (1995) The prenatal development and glucocorticoid control of brushborder hydrolases in the pig small intestine. Pediatr Res 37, $207-212$.

Sawai J (2003) Quantitative evaluation of antibacterial activities of metallic oxide powders $(\mathrm{ZnO}, \mathrm{MgO}$ and $\mathrm{CaO})$ by conductimetric assay. J Microbiol Methods 54, 177-182.

Strugala V, Allen A, Dettmar PW \& Pearson JP (2003) Colonic mucin: methods of measuring mucus thickness. Proc Nutr Soc 62, 237-243.

Torrallardona D, Conde MR, Badiola I, Polo J \& Brufau J (2003) Effect of fishmeal replacement with spray-dried animal plasma and colistin on intestinal structure, intestinal microbiology, and performance of weanling pigs challenged with Escherichia coli K99. J Anim Sci 81, 1220-1226.

van Beers-Schreurs HM, Nabuurs MJ, Vellenga L, Kalsbeek-van der Valk HJ, Wensing T \& Breukink HJ (1998) Weaning and the weanling diet influence the villous height and crypt depth in the small intestine of pigs and alter the concentrations of short-chain fatty acids in the large intestine and blood. J Nutr 128, 947-953. 